\title{
Research Paper \\ The Effect of 8-Weeks of Low-Intensity Swimming Training on Promyelocytic Leukemia Zinc Finger Protein and Spermatid Transition Nuclear Protein Gene Expression in Azoospermic Rats Model
}

\author{
Leila Zohrabi Karani ${ }^{1},{ }^{*}$ Parvin Farzanegi ${ }^{1}{ }^{\oplus}$, Mohamad Ali Azarbayjani ${ }^{2}$
}

1. Department of Exercise Physiology, Sari Branch, Islamic Azad University, Sari, Iran.

2. Department of Exercise Physiology, Tehran Central Branch, Islamic Azad University, Tehran, Iran.

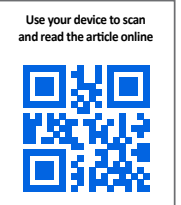

Citation Zohrabi Karani L, Farzanegi P, Azarbayjani MA. [The Effect of 8-Weeks of Low-Intensity Swimming Training on Promyelocytic Leukemia Zinc Finger Protein and Spermatid Transition Nuclear Protein Gene Expression in Azoospermic Rats Model (Persian)]. Quarterly of "The Horizon of Medical Sciences". 2020; 26(4):332-347. https://doi.org/10.32598/hms.26.4.450.2

doif https://doi.org/10.32598/hms.26.4.450.2
Key words:

Swimming, Promyelocytic Leukemia Zinc Finger (PLZF) protein, Spermatid Transition Nuclear Protein (TNP), Azoospermia

\section{A B S TRACT}

Aims One of the causes of infertility in men is the azoospermia disease, which is attributed to the lack of sperm in each sperm. The primary function of spermatogenesis is the maintenance, proliferation, and differentiation of spermatogonial cells. Thus, the present study aimed to investigate the changes in Promyelocytic Leukemia Zinc Finger (PLZF) and spermatid Transition Nuclear Protein (TNP) gene expression levels in an azoospermic rat model after 8 weeks of low-intensity aerobic training.

Methods \& Materials In this experimental study, 15 adult male Wistar rats were randomly divided into three groups of healthy control, with azoospermia, and exercise plus azoospermia after creating an azoospermia model. The patient plus exercise group performed a low-intensity swimming exercise 30 minutes a day, five days a week for 8 weeks, after the creation of the azoospermic rats. A One-way ANOVA test was used for data analysis.

Findings The results showed that a period of swimming exercise program in the exercise plus azoospermia group significantly reduced PLZF gene expression compared to the healthy control groups $(P=0.001)$ and no significant increase to the azoospermia group $(P=0.06)$. There was also a significant decrease in TNP gene expression levels in the exercise plus azoospermia group compared to the healthy control group $(\mathrm{P}=0.001)$ and a significant increase in the azoospermia group $(\mathrm{P}=0.057)$.

Conclusion Based on these Findings, it can be stated that the alteration of key molecules or signaling pathways and expression of the PLZF and TNP genes in the spermatogenesis process may increase infertility, but regular aerobic exercise, such as low-intensity swimming, helps to control the effects of infertility by increasing the maintenance and development of spermatogonial stem cells.

\section{English Version}

\section{Introduction}

permatogenesis is a process that occurs by the proliferation and differentiation of Spermatogonial Stem Cells (SSCs) [1]. These cells are located on the basement membrane of the seminiferous tubules and are surrounded by Sertoli cells [2]. This complex provides an environment that promotes sperm function and survival [3]. Any change in this environment disrupts spermatogenesis, which in turn can lead to temporary or permanent infertility [4]. SSCs form the basis of the process of spermatogenesis and male fertility [5].

\section{* Corresponding Author:}

Parvin Farzanegi, PhD.

Address: Department of Exercise Physiology, Sari Branch, Islamic Azad University, Sari, Iran

Tel: +98 (911) 2230233

E-mail: parvin.farzanegi@gmail.com 
Among the various types of stem cells found in a living organism, SSCs are important because of their ability to pass on genetic information to the next generation; therefore, these cells can be used as a valuable resource for various research studies $[4,5]$. Proliferation and differentiation of spermatogonia cells are the main and primary key in the process of spermatogenesis and maintenance of male fertility [6].

Promyelocytic leukemia zinc finger (PLZF) protein is one of the known markers of SSCs that is essential for the maintenance and development of SSCs in culture [7]. PLZF is produced and secreted by Sertoli cells and subsets of spermatogonia express its receptor [8]. This factor preserves and proliferates spermatogonia stem cells in vitro [9]. In the testes, PLZF is limited to SSC spermatogonia. Studies have shown that after SSC transplantation in rats without PLZF, spermatogenesis does not resume in recipient rats [10]; therefore, one of the possible functions for PLZF could be to maintain a non-differential position [11]. PLZF is considered the basic surface marker of progenitor cells/spermatogonia stem [12].

Another type of sperm nucleoprotein is a protein called spermatid transition nuclear protein (TNP) [13]. These transient proteins make up about $90 \%$ of the major chromatin proteins during the histone deletion and transient protein replacement steps [4]. Laboratory studies have reported that the potential function of TNP protein is to release DNA into nucleosome particles, to reduce the melting point of DNA, and to stimulate topoisomerases-1 activity [14]. In infertile men, spermatozoa have shown many nuclear changes, including abnormal chromatin structure, small chromosomal deletions, aneuploidy, and DNA strand breaks [15].

The results of studies indicate that increasing the expression and signaling of PLZF and TNP is a promising therapeutic strategy for the treatment of azoospermia [16]. In this regard, there are modifiable factors such as a physical activity that help prevent and treat this disease by regulating and modulating genes that are effective in fertility [17], because infertility caused by inactivity has been observed in people with azoospermia, which is a significant concern in medical practice [18]. But the most effective exercise and cellular and molecular mechanisms involved in the exercise are not yet fully clear. Studies show that low-intensity aerobic exercise can reduce the expression of inflammatory cytokines, oxidative stress in testicular tissue, systemic inflammation, and thus improve immune responses by creating a protective mechanism [19].

Among aerobic exercises, low-intensity aerobic swimming exercise is one of the exercises that are safe and usable in various physiological conditions. Also, because of its weight intolerance in water compared to non-water sports, it is used in most physiological, biochemical, and molecular reactions studies [20]. Slow to moderate exercise gradually improves metabolic activity due to increased blood flow, but strenuous activity decreases blood flow due to the change in the direction of blood flow to active muscles [20]. Decreased physical activity can reduce the amount of sex hormones, sperm production, and fertility, as well as shrink the testicles and reduce the amount of sperm [21].

A study by Ferenc et al. (2014) reported that after 12 weeks of moderate-intensity aerobic exercise, spermatogenesis markers such as PGC- $1 \alpha$ (peroxisome proliferatoractivated receptor-gamma coactivator-1) and PLZF were improved in rats [22]. In a review study by Vaamonde et al. (2017), it was reported that after a period of low- and moderate-intensity aerobic exercise, the level of azoospermia decreases by modulating the genes involved in the disease and reducing the level of oxidative stress and inflammation in these patients, and the quality of sperm and fertility increase [23]. In this regard, the results of studies showed that high-intensity exercise can lead to negative and positive changes in genes that affect sperm fertility such as PLZF and TNP [24]. Although possible mechanisms have been suggested, the results of studies on the relationship between physical activity and the rate of azoospermia are not conclusive. Therefore, because of the importance of preventing the causes of azoospermia, the lack of necessary and sufficient information about the effect of exercise on the expression of PLZF and TNP gene in azoospermia, the present study aimed to investigate the effect of 8 weeks of low-intensity swimming exercise on PLZF and TNP gene expression in azoospermic rats.

\section{Materials and Methods}

In this experimental study, 15 adult male Wistar rats aged 6-8 weeks with a Mean \pm SD weight of $202.85 \pm 15.62$ $\mathrm{g}$ were purchased from the Pasteur Institute. The animals were kept in special polycarbonate cages in an environment with an average temperature of $22 \pm 1.4^{\circ} \mathrm{C}$, the humidity of $55 \%$, and a light-dark cycle of 12:12 hours. The animals were cared for following the guidelines of the International Institute of Health and the protocols of this study, following the principles of the Helsinki Declaration and the rules of medical ethics [25]. The animals were treated with free pellet food and water. The food consumed by the animals was given to the animal at the rate of $10 \mathrm{~g}$ per $100 \mathrm{~g}$ of body weight according to the weekly weight gain. 
To create the azoospermia model, busulfan $(40 \mathrm{mg} / \mathrm{kg}$ body weight) was first injected intraperitoneally into each rat. One month after induction of the model in the rats, they were randomly divided into 3 groups: Healthy control (5 heads), azoospermia (5 heads), and exercise plus azoospermia (5 heads) $[4,5]$. The azoospermic group remained one month after modeling until the end of the study ( 8 weeks) and the healthy control group was kept for 8 weeks, and the exercise plus azoospermia group swam for 8 weeks, one month after the development of azoospermia.

Before the start of the main protocol, the rats in the exercise plus azoospermia group got acquainted with the water and swimming and adapted to exercise conditions for 20 minutes per day for 5 days. Then, 5 days a week until the end of the research period, they swam in a water tank measuring $50 \times 50 \times 100 \mathrm{~cm}$ with a temperature of $30^{\circ} \mathrm{C}-32^{\circ} \mathrm{C}$ for 8 weeks. The duration of exercise in water was 30 minutes daily until the end of the exercise period.

To eliminate the acute effect of exercise, the animals were sampled 48 hours after the last swimming exercise program. For this purpose, the animals were first anesthetized using an intraperitoneal injection of ketamine $(50-30 \mathrm{mg} / \mathrm{kg})$ and $\mathrm{xy}-$ lazine (3-5 mg/kg) and then were killed. Afterward, their tissues around the testicular area were evaluated for histology and genetic studies. For this purpose, tissue samples were transferred to $10 \%$ formalin and samples related to gene expression were transferred to a nitrogen tank.

A real-time PCR technique was used to evaluate the expression of PLZF and TNP genes in each tissue analysis group. First, primer design was performed and then total RNA was extracted from tissues and converted to cDNA. Then cDNA was amplified by PCR and RT-qPCR technique was used to confirm quantitatively the expression of the studied genes. To this end, first, whole-cell RNA was extracted using Kiazol solution according to CinnaGen protocol and exposed to DNase I Fermentas to ensure contamination with genomic DNA. Besides, gel electrophoresis was used to evaluate the integrity of the extracted RNA.

To extract RNA, the first 200-300 Landa Chiazol was added to the testicular tissue and it was maintained at $-80^{\circ} \mathrm{C}$ for 24 hours. Then, the plaque in the Cryotube was crushed in a semi-frozen state by a sampler and then slightly pipetted. About 100 landa chloroforms were then added to the sample to lyse the cells. This solution should be in contact with the cell for about 1 minute. Afterward, the solution was centrifuged at $12000 \mathrm{rpm}$ for 10 minutes. Next, the solution was divided into three parts: the upper part of the tube, which was clear and contained RNA; the middle part of the tube, which was white and had the lysed texture; and the lower part of the tube which was pink and contained Chiazol. The clear liquid at the top of the tube containing the RNA was gently removed and placed in a DEPC microtube. Then $1 \mathrm{~mL}$ of isopropanol was poured on clear RNA and stirred by hand for 1 minute. Isopropanol is clear and RNA is clear, but when the two are mixed, they form a turbid liquid. After adding isopropanol, the samples were centrifuged at $12000 \mathrm{rpm}$ for 10 minutes. After removing from the centrifuge, the supernatant was drained and $1 \mathrm{~mL}$ of $70 \%$ alcohol was added. After vortexing, the mixture was centrifuged at $7500 \mathrm{rpm}$ for 10 minutes. The supernatant was then drained with a sampler and then the plaque was dried inside a microtube. To dissolve RNA, 20 landa $60^{\circ}$ distilled water was poured on the plate inside the microtube. It was then pipetted slightly with a sampler and placed on a $60^{\circ}$ plate for 5 minutes.

Also, for the preparation of single-stranded cDNA, Oligo (dt) (MWG-Biotech primer, Germany) and reverse transcription enzyme (Fermentas company) were used and performed according to the manufacturer's instructions. Each PCR reaction used PCR Master Mix (Applied Biosystems) and SYBR Green (Applied Biosystems), and Sequences Detection Systems. Foster City, CA (ABI Step One) was done according to the manufacturer's protocol. Forty cycles were considered for each cycle of real-time PCR, and the temperatures of each cycle were set at $94^{\circ} \mathrm{C}$ for 20 seconds, $58^{\circ} \mathrm{C}-60^{\circ} \mathrm{C}$ for 30 seconds, and $72^{\circ} \mathrm{C}$ for 30 seconds. A melting diagram was drawn to evaluate the accuracy of PCR reactions and was evaluated specifically for each gene and in each reaction with a negative control diagram to check for contamination in each reaction.

The expression ratio of the genes studied in this study was evaluated by the threshold cycle comparison method (Threshold Cycle: TC) using the data in the Formula 1:

$$
\begin{aligned}
& \text { 1. } R=2^{-(\Delta \Delta C)} \\
& \Delta \Delta C T=\left(C^{\text {Ttanget_}} C^{\text {Trefence }}\right) \text { Time } X\left(C^{\text {Ttarget_t}} C^{\text {Trefence }}\right)_{\text {Time } 0}
\end{aligned}
$$

The specific standard curve of each gene was plotted using at least 5 logarithmic concentrations in diluting order of positive control of each gene. The expression level of the target gene was normalized with the reference gene and the expression of genes in the healthy group was considered as a calibrator (Formula 2).

$$
\begin{aligned}
& { }^{2 .} \text { Ratio }=\frac{(\text { Etarget })^{\Delta C T}{ }_{\text {target }}}{(\text { Ereference })^{\Delta C T_{\text {reference }}}} \\
& \left(\Delta C t_{\text {refience }}=C t_{\text {control }}-C t_{\text {treatment }}, \Delta C t_{\text {target }}=C t_{\text {control }}-C t_{\text {treatment }}\right)
\end{aligned}
$$


In the above formula, E represents efficiency and is obtained by drawing a standard curve for the gene [26].

After in vitro analysis of tissue samples, descriptive statistics including mean and standard deviation and inferential statistics were used to quantitatively describe the data. First, the Shapiro-Wilk test was done to determine the normality of the data distribution, and then Levene's test was used to determine the homogeneity of variance. Because of the normal distribution of data, parametric tests, including 1-way analysis of variance and Tukey post hoc test at a significance level of $\mathrm{P} \leq 0.05$ were used to examine changes in PLZF and TNP gene expression. SPSS version 23 was used to perform all statistical tasks and Excel software was used to draw the chart.

\section{Results}

Table 1 presents the mean weight of rats in the different studied groups. The results of the 1-way analysis of variance showed no significant difference in the weight of rats in different groups $(\mathrm{P} \geq 0.05)$.

The results of the Tukey post hoc test showed that 8 weeks of low-intensity aerobic swimming exercise significantly re- duced the level of PLZF gene expression in the exercise plus azoospermia group compared to the healthy control group (125.42\%) and a non-significant increase compared to the azoospermia group $(42.47 \%)(\mathrm{P}=0.001, \mathrm{P}=0.06$, respectively) (Figure 1).

The results of the Tukey post hoc test indicate that 8 weeks of low-intensity aerobic swimming exercise significantly reduced the expression level of the TNP gene in the exercise plus azoospermia group compared to the healthy control group (104.93\%) and no significant increase compared to the azoospermia group $(265.76 \%)(\mathrm{P}=0.001, \mathrm{P}=0.057$, respectively) (Figure 2).

\section{Discussion}

In the present study, the effect of 8 weeks of low-intensity swimming exercise on PLZF and TNP gene expression in azoospermia rats was investigated. One of the important results of the present study is a significant decrease in PLZF and TNP gene expression levels in azoospermia rats compared to the healthy group. The results of the present study are consistent with the results of the studies of some researchers who stated that azoospermia alters the expression of genes involved in fertility such as PLZF and TNP [22-24].

Table 1. The Mean and Standard Deviation of rats' weight in the studied groups

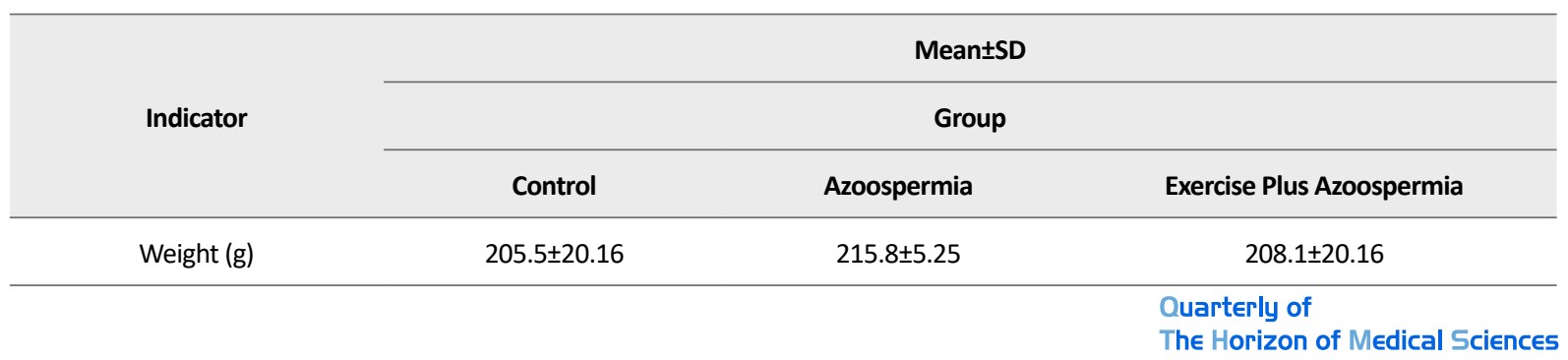

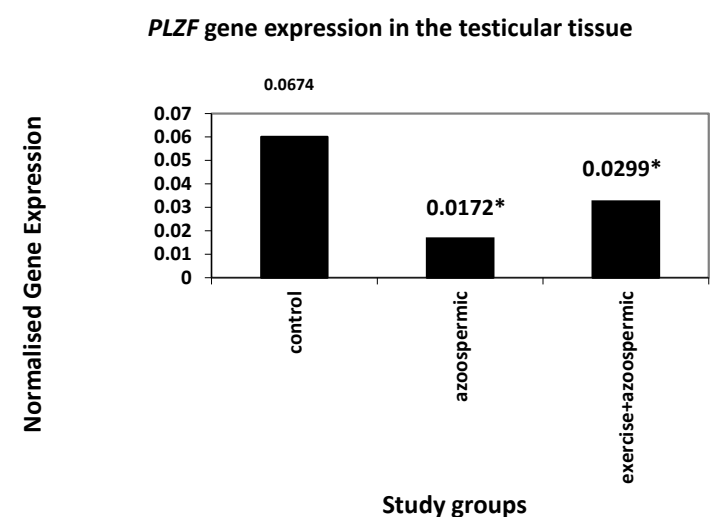

tudy groups

Figure 1. Comparison of mean mRNA levels for PLZF gene expression between different studied groups

\footnotetext{
* Significant change compared to the control group $(\mathrm{P} \leq 0.05)$.
} 


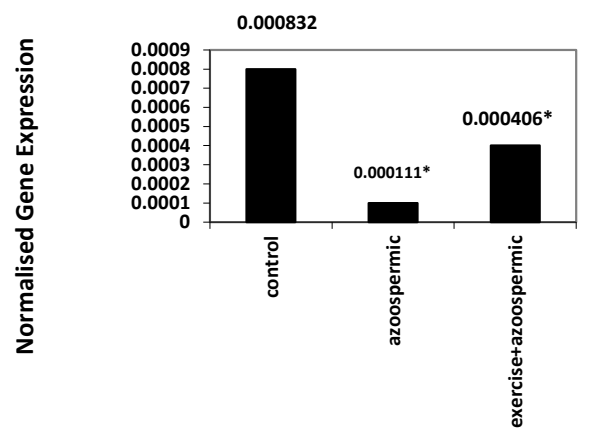

Study Group

Quarterly of

The Horizon of Medical Sciences

Figure 2. Comparison of mean mRNA levels for TNP gene expression between different study groups

* Significant change compared to the control group $(\mathrm{P} \leq 0.05)$.

PLZF and TNP have been identified as key markers in the maintenance and development of spermatogonia stem cells [27]. The results showed that in infertile sperms there are many nuclear changes, including the abnormal structure of chromatin and DNA strand breaks that lead to changes in the expression level of this gene [13]. This gene, which plays a role in the proliferation and differentiation of spermatogenesis stem cells, has different receptors in most tissues of the body, such as the testes, and is important for the maintenance and development of stem cells [28].

Chen et al. in their study acknowledged that azoospermia leads to decreased growth and development and even the proliferation and differentiation of stem cells, and decreased sperm production quality leads to decreased expression levels of PLZF and TNP genes [18]. Decreased levels of SSCs receptors inhibit the production and expression of spermatogonia stem cells [29]. Therefore, it seems that reducing the receptor and increasing inflammation in azoospermic patients can reduce the expression level of PLZF and TNP genes [28].

The results of the present study also showed that 8 weeks of low-intensity swimming exercise caused no significant increase in PLZF and TNP gene expression in rats in the swimming exercise group compared with the azoospermia group. Because a clear mechanism for the effect of physical activity on PLZF and TNP gene expression has not yet been properly elucidated, it is impossible to properly explain the research Findings. The results of some similar studies showed the improving effect of aerobic exercise on the expression of spermatogonia stem cells [21-24]. Frances et al. in their study acknowledged that aerobic exercise, especially moderate-intensity aerobic exercise could affect, modulate, and improve spermatogenesis markers such as PLZF and TNP and reduce the level of inflammation in infertile patients [22]

In line with the results of this study, it was shown that aerobic exercise increases the level of sexual quality and fertility due to the reduction in the expression of inflammatory genes and the improvement of spermatogonia stem cells [23]. Physical activity can release nitric oxide that activates the enzyme guanyl cyclase, resulting in increased levels of cGMP (cyclic guanosine monophosphate). This increase leads to the dilation of the arteries of the reproductive system and increases its blood flow, which in turn leads to increased sperm production [30]. These changes reduce the risk of infertility in men who have become infertile due to a lack of sperm [31]. In other words, physical activity leads to increased sperm production and treatment of infertility due to spermatogenesis by dilating blood vessels and increasing the blood flow cycle in organs such as the reproductive system [32]. Also, increasing capillary density in response to exercise leads to adequate oxygen supply to the tissue, which in turn activates and alters cell membrane permeability, thereby increasing mRNA production and cell division, and the expression level of spermatogonia stem cell genes increases [33].

In their study, Faustino-Rocha et al. (2017) acknowledged that increasing capillary density and blood flow improves stem cell surface area, motility, differentiation of fertile cells [23]. Also, research on the effect of physical activity on spermatogonial stem cells shows that following physical activity, especially aerobic, the cellular response begins with the activation of photoreceptors in the respiratory chain located in the mitochondria, resulting in altered cel- 
lular redox. It modifies and together with changes in cell membrane state with calcium transfer and $\mathrm{pH}$ changes and activation of CAMP (cyclic adenosine monophosphate) and DNA duplication leads to the formation of new proteins and cell proliferation [34]. In this way, cellular responses are drawn from the cellular surface to the surface of tissue and organs and effects such as cell proliferation, neovascularization, aerobic metabolism shift, and fertility balance and infertility reduction are achieved $[35,36]$.

\section{Conclusion}

In general, the results of the present study indicate that alteration of key molecules or signal pathways and expression of PLZF and TNP genes in the process of spermatogenesis can reduce fertility and increase infertility, but regular aerobic exercise, such as low-intensity swimming, treats infertility by increasing the maintenance and development of spermatogonia stem cells.

\section{Ethical Considerations}

\section{Compliance with ethical guidelines}

The researchers followed all the ethical rules related to animal Research Protocols (Ethics Code: IR.IAU.SARI. REC.1398.149).

\section{Funding}

The present paper was extracted from the $\mathrm{PhD}$. thesis of the second author, Department of Exercise Physiology, Sari Branch, Islamic Azad University, Sari.

\section{Authors' contributions}

Data collection: Leila Zahrabi Korani; Research idea presentation, study design, writing, and editing the manuscript: Parvin Farzangi; Data analysis and initial review: Mohammad Ali Azarbayjani.

\section{Conflicts of interest}

The authors declared no conflict of interest. 
This Page Intentionally Left Blank 


\title{
تأثير \ هفته تمرين شنا با شدت يايين بر بيان ثن PLZF و TNP در موشهاى صحرايى مدل

\author{
ليلا ظهرابى كرانى'، "يروين فرزانكى' 'ه، محمدعلى آذربايجانى' \\ 1. كروه فيزيولورثى ورزشى، دانشكاه آزاد اسلامى، واحد سارى، سارى، ايران.

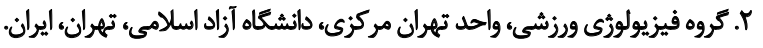

مداف يكى ازعلل نابارورى در مردان بيماري آنواسيرمى است كه به نبود اسيرم در هر انزال اطلاق ميشود. حفظ، تكثير و مثايز سلولهاي

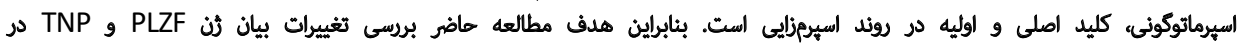

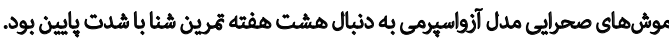

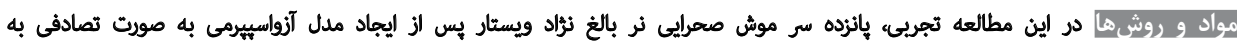

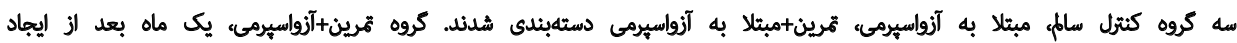

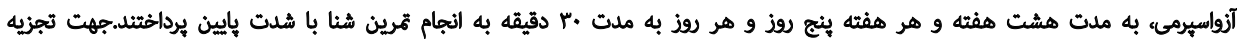
و تحليل دادهها آزاليز واريانس يكات مثرفه استفاده شد.

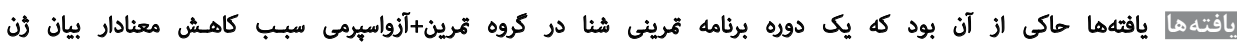

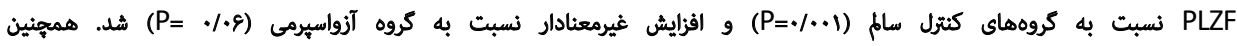

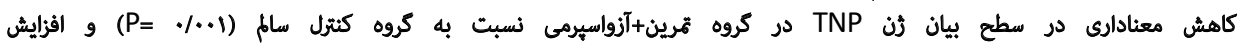

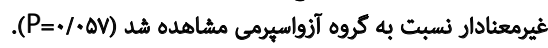

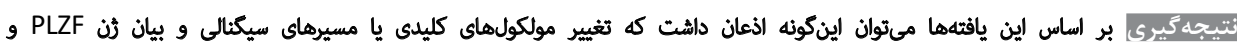

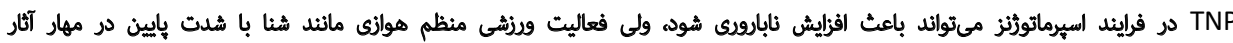

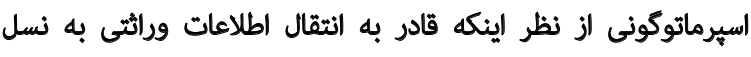

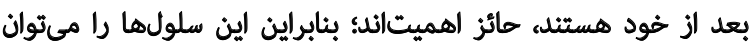

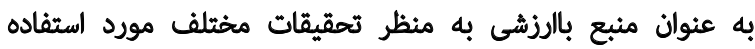

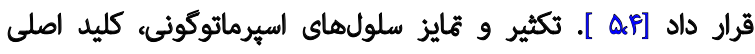
و واوليه در روند اسيرمزايى و حفظ بارورى مردان هستئد [9].

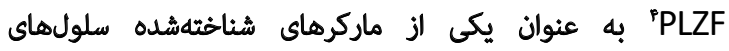

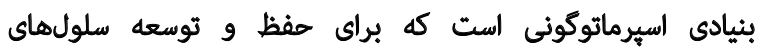

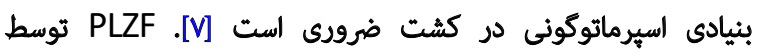

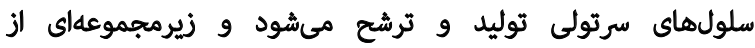

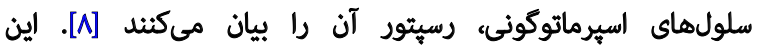
فاكتور باعث هفظ و تكثير سلولهاى بنيادى اسيرماتوكونى آنى

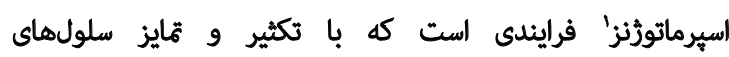

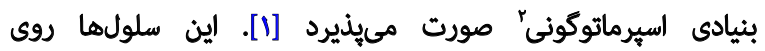

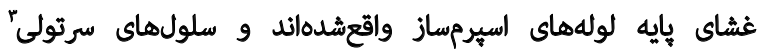

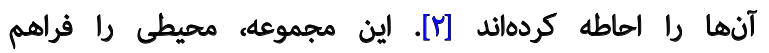

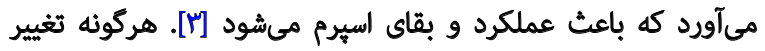

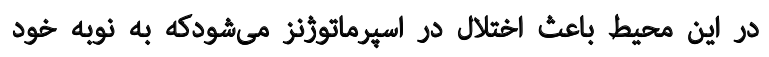

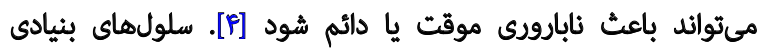

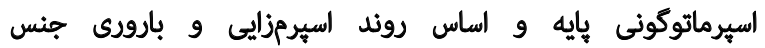
مذكر را تشكيل مىدهند [ه]]. از ميان انواع مخثلف سلولهائ بارئ

\section{Spermatogenesis}

2. Spermatogonial Stem Cells (SSCs)

3. Sertoli cells

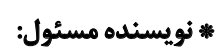

$$
\begin{aligned}
& \text { دكتر يروين فرزانكى } \\
& \text { نشائى: كروه فيزيولوزئ ورزشى، دانشكاه آزاد اسلامى، واحد سارى، سارى. }
\end{aligned}
$$

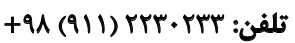

$$
\begin{aligned}
& \text { parvin.farzanegi@gmail.com: يست الكترونيكي: }
\end{aligned}
$$


تا متوسط به علت افزايش جريان خون بهتدريج سبب بهبود

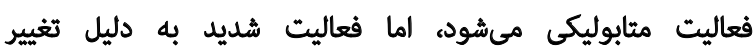

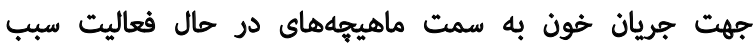

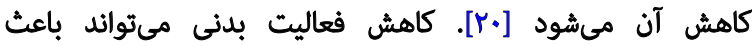

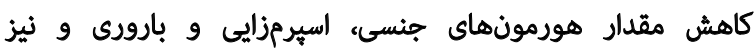

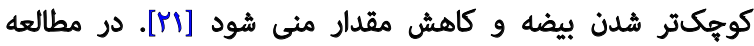

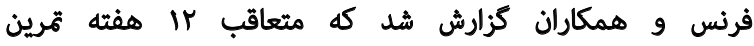

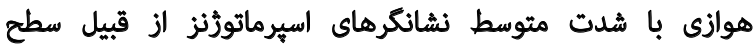

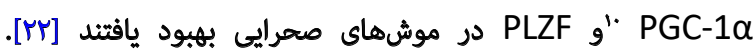

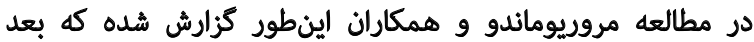

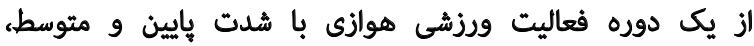

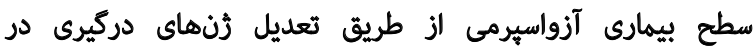

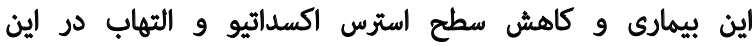

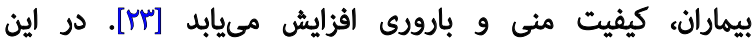

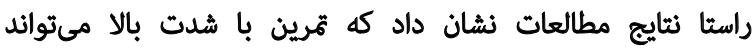

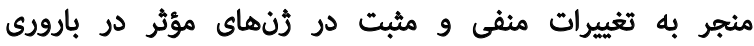

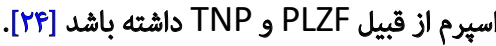

مكانيسمهاى مصتملى نيز بيشنهاد شده است، اما ثنايج

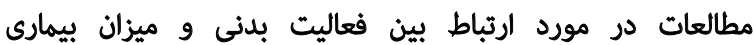

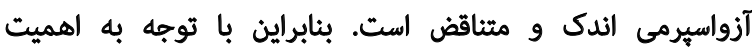

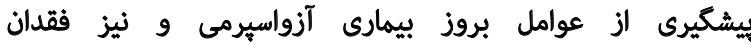

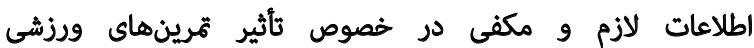

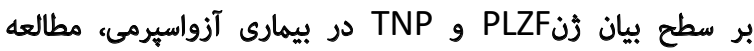

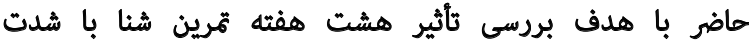

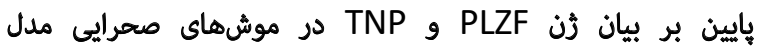
آزواسيرمى انجام كرفت. يان.

$$
\text { مواد وروش اشنا }
$$

در اين مطالعه تجريى هائزده سر موش صحرايى نر بالغ نزاد

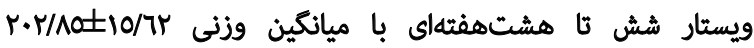

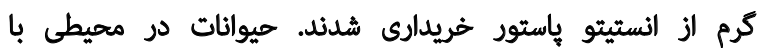

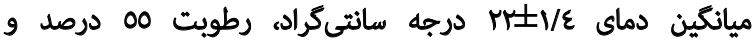

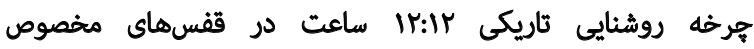

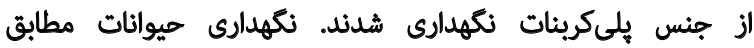

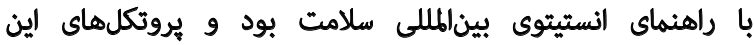

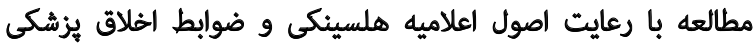

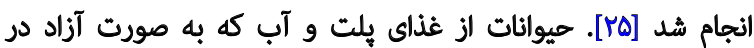

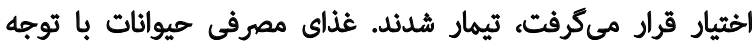

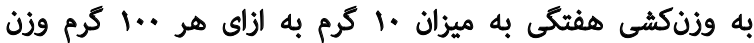
بلن در اختيار حيوان قرار داشت.

10. Peroxisome proliferator-activated receptor-gamma coactivator-1
در شرايط آزمايشكاهى مىشود [9]]. در بيضه PLZF محدود به

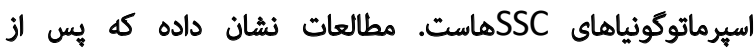
بيوند SSC ها از موشهاى بدون PLZF، در موش كيرنده روندان

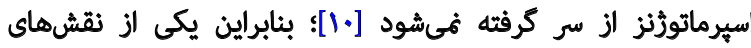

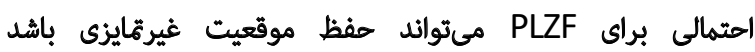

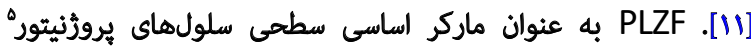
إبنيادى اسير ماتوكونى محسوب مىشود [IIT]

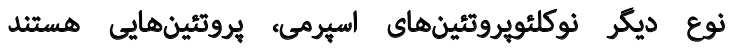

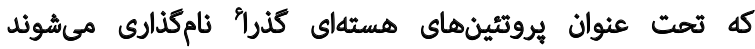

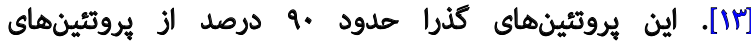

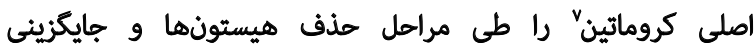

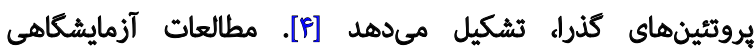

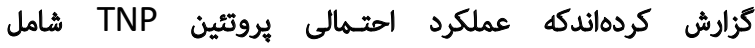

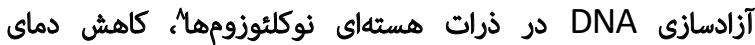

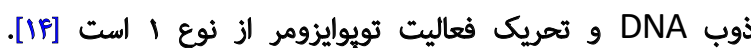
مشخص شله است كه در مردان نابارور اسيرماتوزوها تغييرات

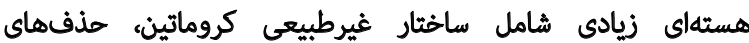

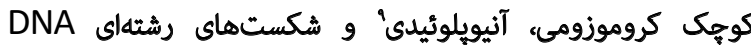

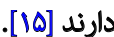

نتايج مطالعات بيانكر آن الهث كه افزايش بيان و سيكنالينك

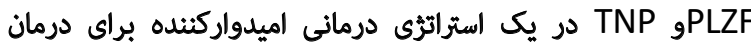

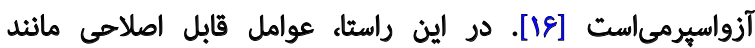

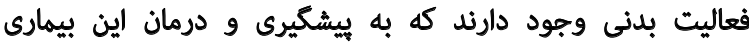

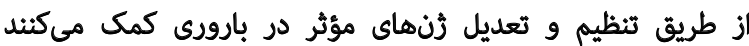

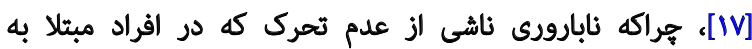

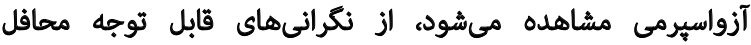

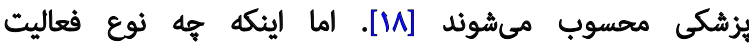

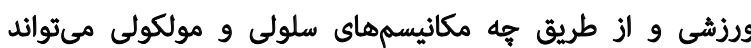

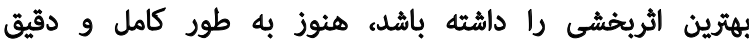

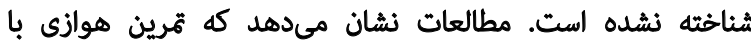

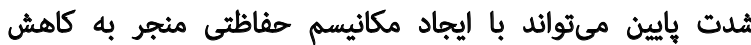

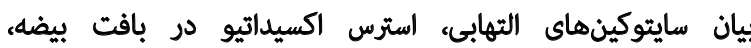

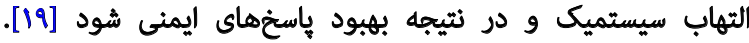

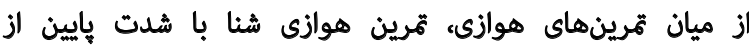

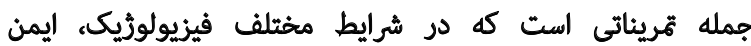

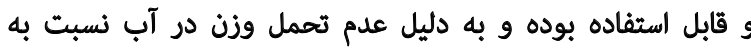
ورزشهاى غيرآبى در اكثر مطالعات فيزيولوزيكى، بيوشئيميايى

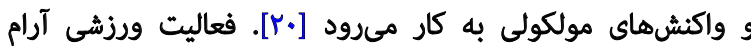

\section{Progenitor cell}

6. Spermatid nuclear transition protein (TNP)

7. Chromatin

8. Nucleosome

9. Aneuploidy 
جهت استخراج RNA ابتدا به بافت بيضه ..r-..r لاندا

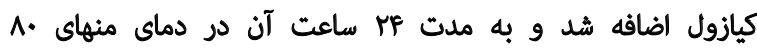

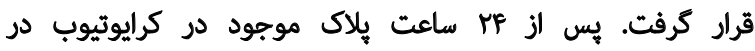

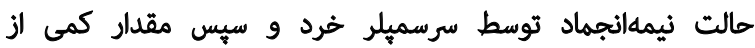

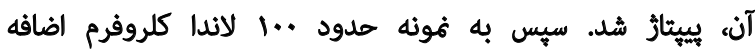

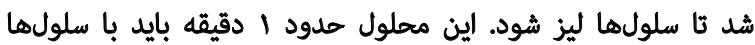

در متاس بود.

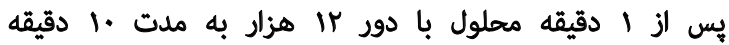

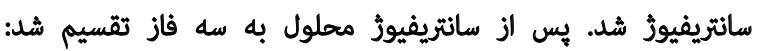
قسمث بالايى لوله كه شفاف و حاوى RNA بود، قسمث وسطى

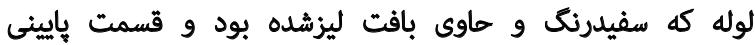

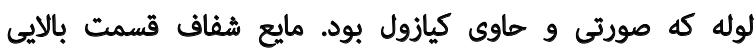

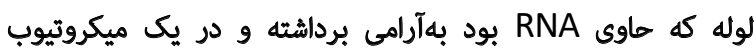

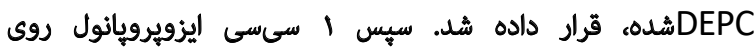
RNA

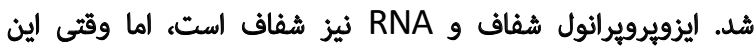

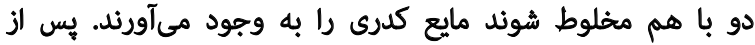

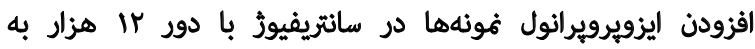

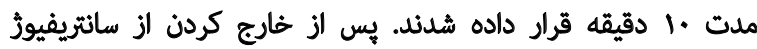

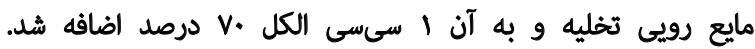

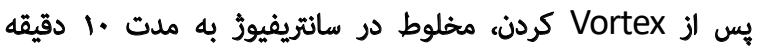

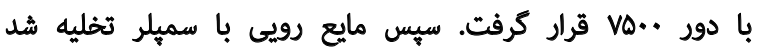

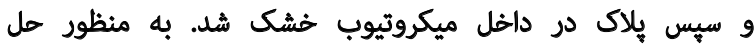

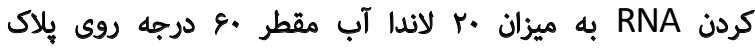

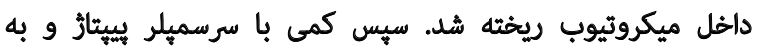

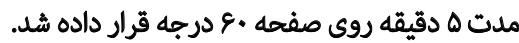

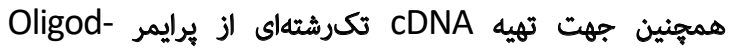
tMWG-Biotech, Germany (شركت فرمنثاز "Fermentas") استفاده شد و و برائ اين كار

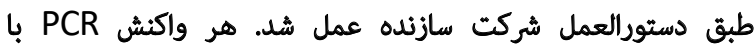
الستفاده از SYBER و PCR master mixApplied Biosystems Applied Biosystems, Sequences De- در دستكاه Green (tectionSystems. Foster City, CA (ABI Step One يروتكل شركت سازنده انجام كرفت. جهل سيكل براى هر هرخه Real-Time PCR

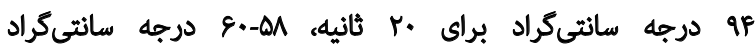

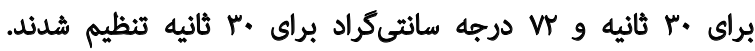
غودال Melting جهت بررسى صحت واكنشهاى PCR ترسيم

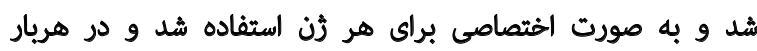

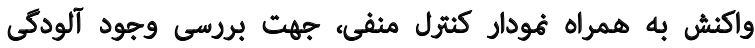
در هر واكنش مورد الرزيابى قرال كرفت.

نسبت بيان رُنهايى موردبررسى در اين مطالعهء با روش

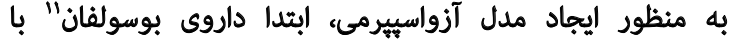

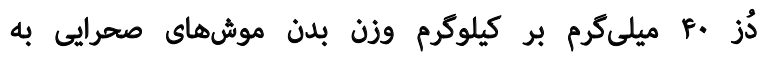

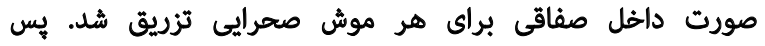

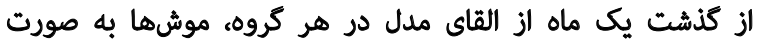
تصادفى به سه كروه كنتزل سامل (ينج سر)، آزواسيرمى (ينج

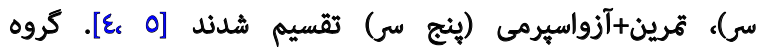

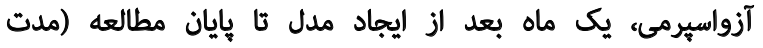

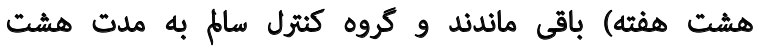

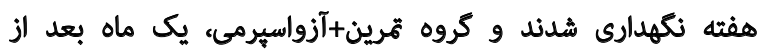

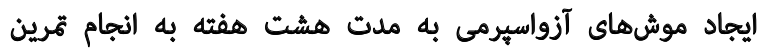
شنا يرداختند.

موشهاى صحرايىكروههاى تمرين+آزواسيرمى، قبل از شروع

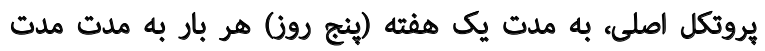

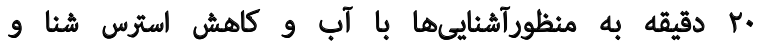

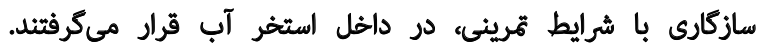

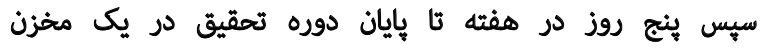

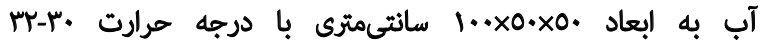

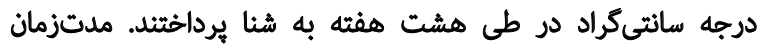

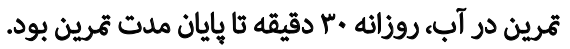

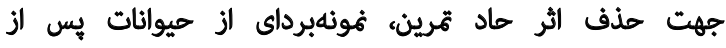

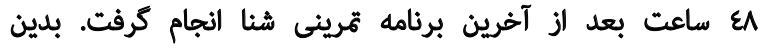

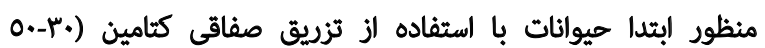

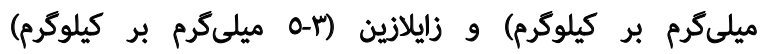

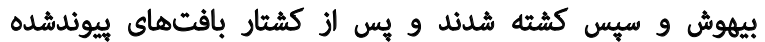
مريوط به ناهيه بيضه جهت بررسى بافتشناسى و مطالعات رٔنى

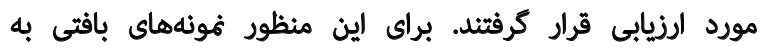

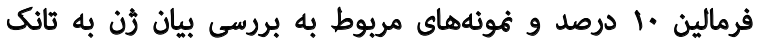
ازت منتقل شدند.

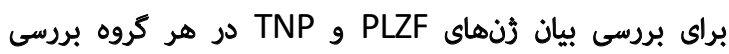

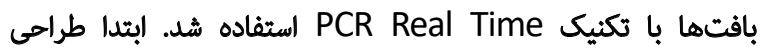
يرايمر انجام شد و سيس RNA كل از بافيستها استخراج شد و به cDNA تبديل شد. سيس CDNA به روش و الز تكنيك RT-qPCR جهت تأييد بيان ثرنهاى موردمطالعه به صورت كمى استفاده شد. براى اين منظور ابتدا با استفاده

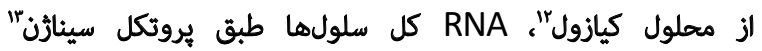

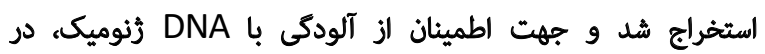
معرض DNase IFermentas قرار كرفت. علاوه بر اين، جهيت الودئ ارزيابى يكيارجكى RNA استخراج شده الز خل الكتروفورز استفاده 
دادهها از شاخصهاى آمار توصيفى شامل ميانكين و انحراف

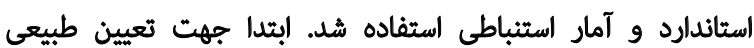

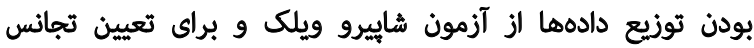

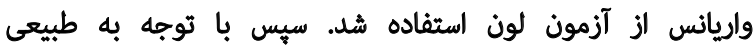
بودن نحوه توزيع دادهها الز آزمون يارامتريك شامل آزمون تحليل آناديل

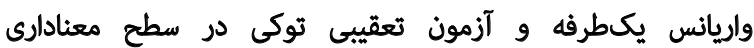

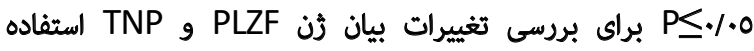

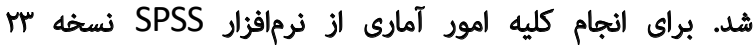
استفاده شد و براي رسم ثمودار از نرمافزار اكسل استفاده شدم.

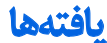

جدول شماره ا، ميانكين وزن موشهاى صحرايى دركروههاى

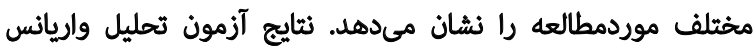

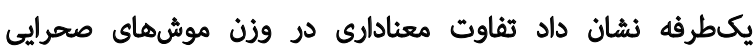

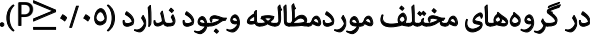
نتايج آزمون تعقيبى توكى نشان داد هشت هفته تمرين هوازى

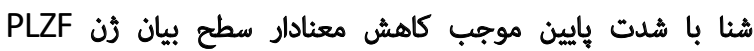

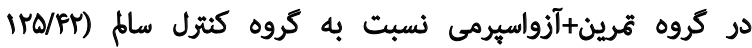

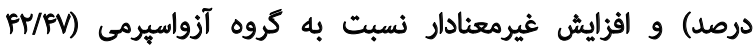

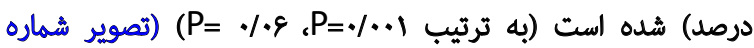

مقايسهاى هرخه آستانه" مورد الززيابى قرار كرفتند. با استفاده الز

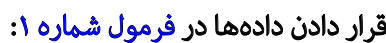

$R=2^{-(\Delta \Delta C T)}$

$$
\Delta \triangle C T=\left(C T_{\text {target }}-C T_{\text {refence }}\right)_{\text {Time } X}\left(C T_{\text {target }}-C T_{\text {refence }}\right)_{\text {Time } 0}
$$

منحنى استاندارد اختصاصى هر ثٔن با استفاده از حداقل ينج

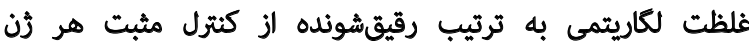

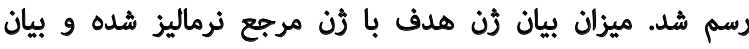

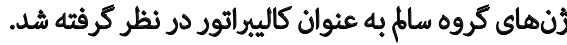

$$
\begin{aligned}
& \text { Ratio }=\frac{\left(E_{\text {target }}\right)^{\Delta C T_{\text {target }}}}{\left(E_{\text {reference }}\right)^{\Delta C T_{\text {reference }}}} \\
& \left(\Delta C t_{\text {refrence }}=C t_{\text {control }}-C t_{\text {treatment }}, \Delta C t_{\text {target }}=C t_{\text {control }}-C t_{\text {treatment }}\right)
\end{aligned}
$$

در فرمول شماره Y معرف Efficiency الست و با استفاده الز

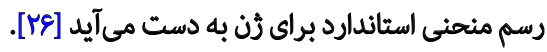
بعد از تحليل آزمايشكاهى نموذهاى بافتى، براى توصيف كمى

\begin{tabular}{|c|c|c|c|}
\hline \multicolumn{3}{|c|}{ مياتكين ثانحراف معيار } & \multirow[t]{2}{*}{ كروه } \\
\hline تمرين+آزواسيرمى & آزواسيرمى & كتيترل & \\
\hline$r \cdot N / \pm 1 Q / 8$. & $M / \Delta / A \pm \Delta / Y \Delta$ & $r \cdot \Delta / \Delta \pm r \cdot / 1 \varepsilon$ & ونزن (5رم) \\
\hline
\end{tabular}
14. Thereshold Cycle (CT)

جدول ا. ميانكين و انحراف معيار وزن موشها در تروههاى مختلف موردمطالعه औin

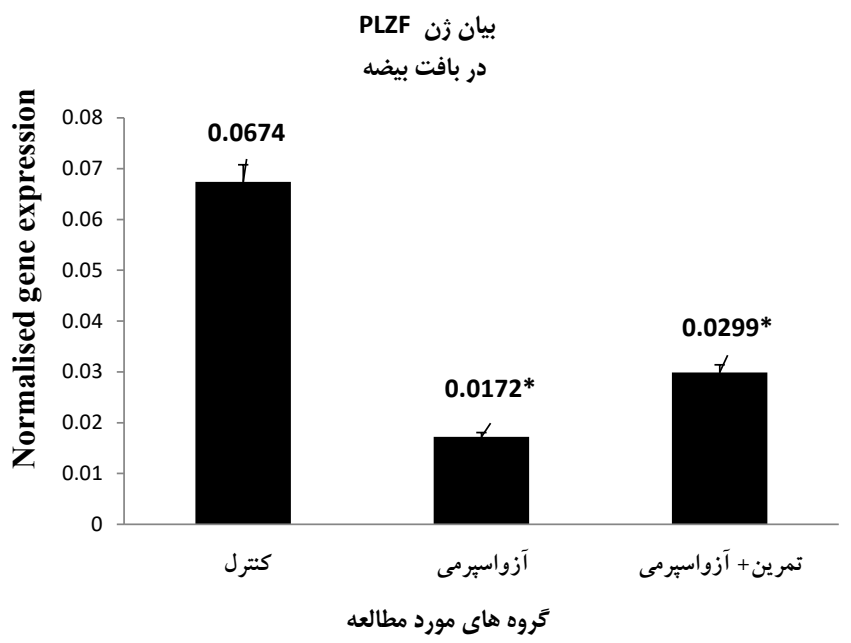

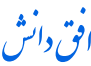
تصوير ا. مقايسه سطوح ميانكين mRNA براي بيان ثن PLZF بافت بيضه بين كروهاي مختلف موردمطالعه

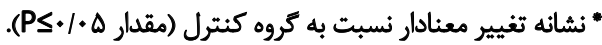




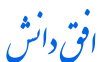

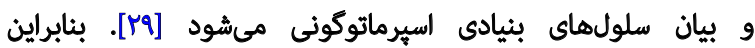

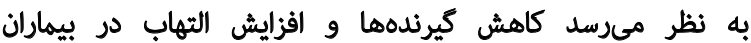

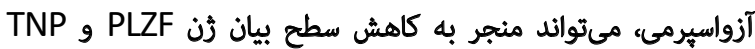

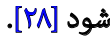

هميجين نتايج تحقيق حاضر نشان داد كه هشت هفتله تمرين

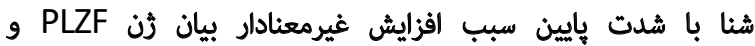
موشهاى صحرايى كروه تمرينى شنا در مقايسه با كروه

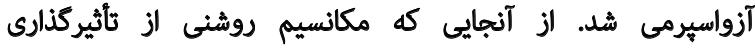

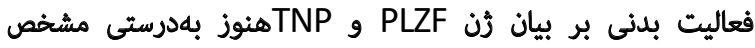

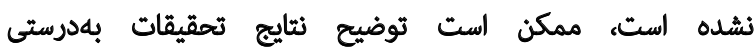
امكانيذير نباشد. نتايج برخى از مطالعات همراستا بانئ نتايج تهقيق

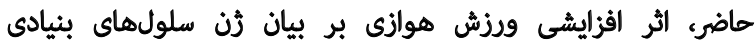

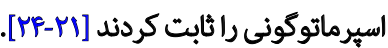

فرنس و همكاران در مطالعه خود اينكونه اذعان داشتئد كه

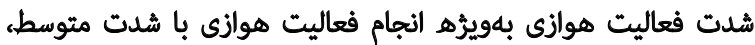

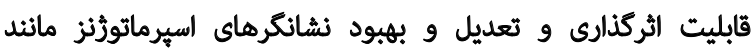
و و PLZF

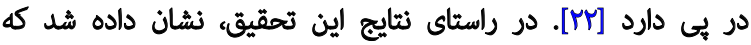

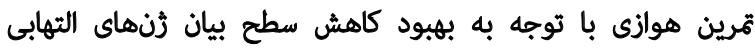

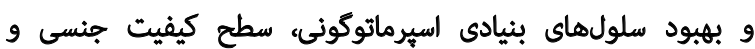

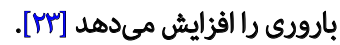

فعاليث بدنى ميتوائد باعث آزاد شدن اكسيد نيتريكها شود.

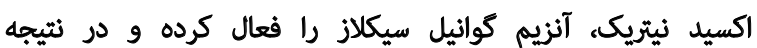

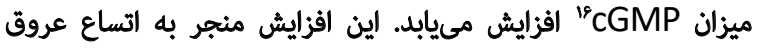

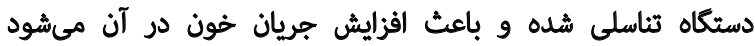

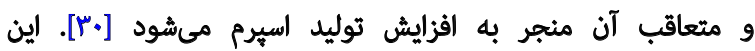

15. Nitric Oxide

16. Cyclic Guanosine Monophosphate
بيان زن ThP

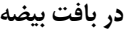

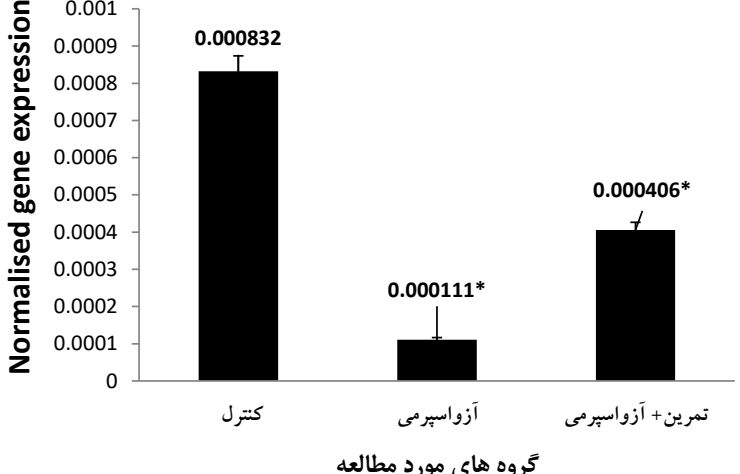

كروه هاي مورد مدان

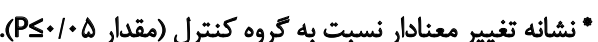
نتايج بررسى آزمون تعقيبي توكى بيانكر آن است كه هشت هيت

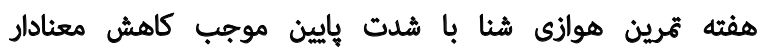

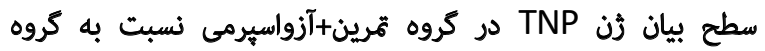

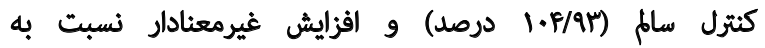
كروه آزواسيرمى (تهو/VY)

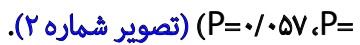

ب

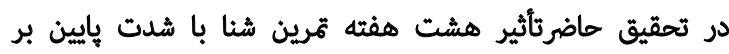

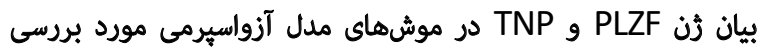

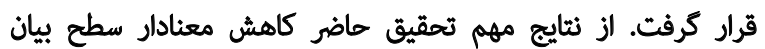

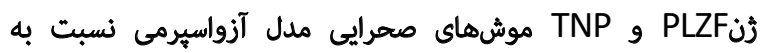

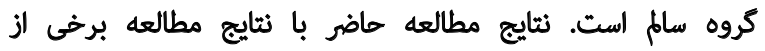

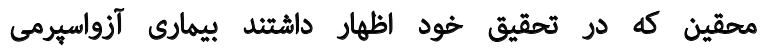

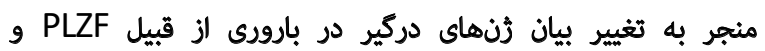

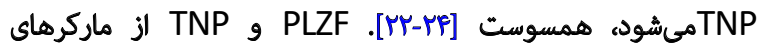
اساسى در حفظ و توسعه سلولهاى بنيادى اسيرماتوكونى شناخته شدند [TV] نتايج تحقيقات نشان داد كه درمردان نابارور السيرماتوزوها

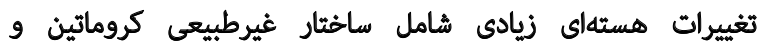

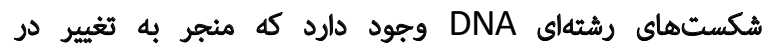

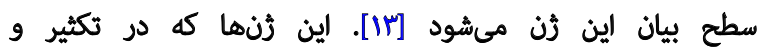

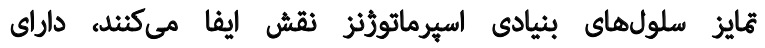

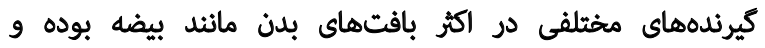
جهت حفظ و توسعه سلولهاى بنيادى داراى اهميت هذيت هستئد

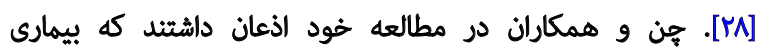
آزواسيرهى منجر به كاهش سطح رشد و وتوسعه و و هتى تكثير

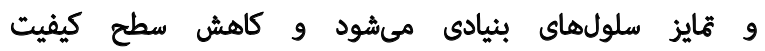

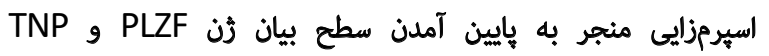

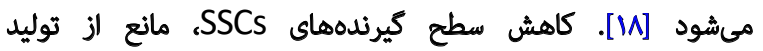


هزينه مالى اين مطالعه به صورت شخصى تامين شده است.

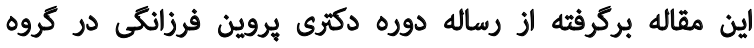

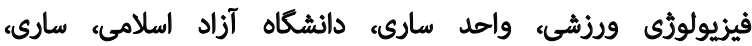

\section{مشاركت نويسند كَان}

جمعآورى دادهها: ليلا ظهرابى كوراني؛ ارائه ايده تهقيق،

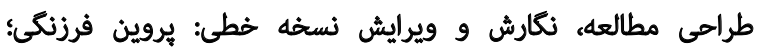
تجزيه و تحليل دادهها و بررسى اوليه: محمدعلى آذربايجانى. نكارئ

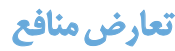
هيجكونه تعارض منافعى توسط نويسندكان بيان نشده است.
تغييرات باعث كاهش اهتمال نابارورى در افرادى مىشود كه به به

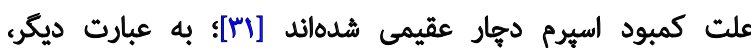

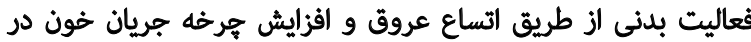

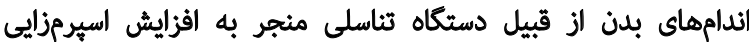

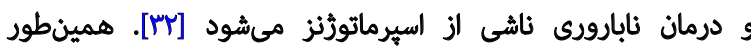

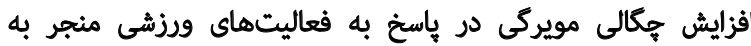

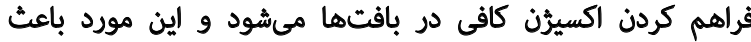

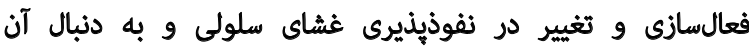

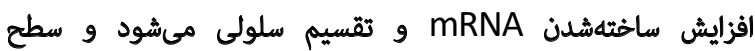

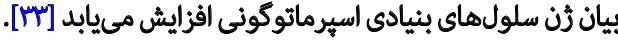
جوزكو و همكاران در مطالعه خود اذعان داشتند كه افزايش جكالى مويركى و جريان خون، منجر به بهان بهبود سطح و و تحرى

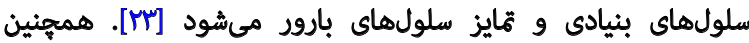

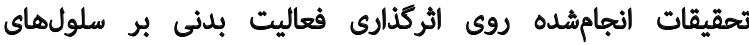

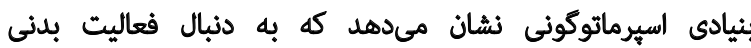

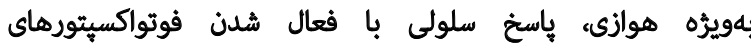

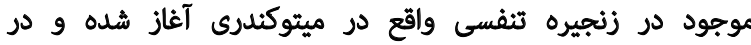

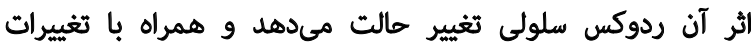

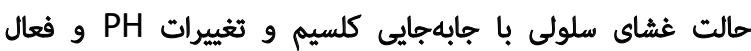

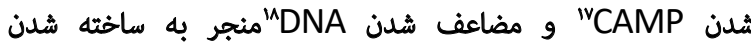

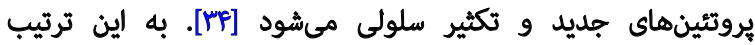

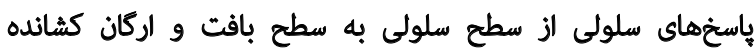

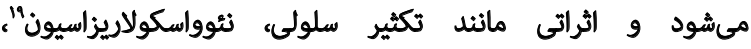

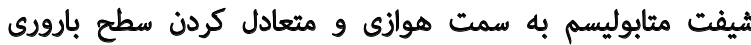

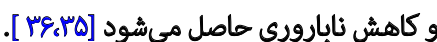

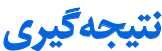

به طور كلى نثايج تهقيق حاضر بيانكر آن است كه تغيير

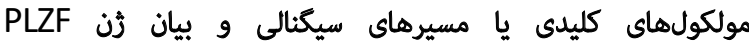

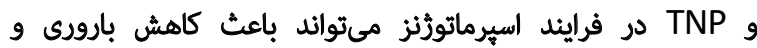

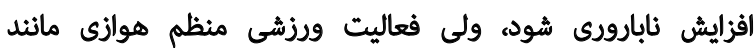

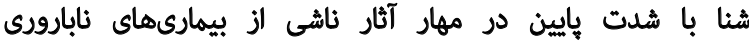

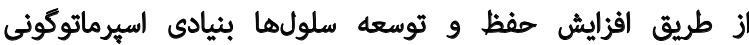

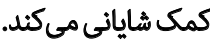

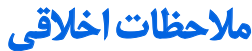

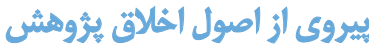

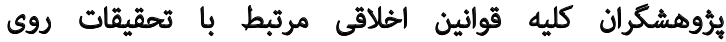

IR.IAU.SARI. حيوانات را رعايت كردند. اين مطالعه با كد اخلانين

17. Cyclic Adenosine Monophosphate

18. Duplication

19. Neovascularization 


\section{References}

[1] Ernst C, Eling N, Martinez-Jimenez CP, Marioni JC, Odom DT. Staged developmental mapping and $\mathrm{X}$ chromosome transcriptional dynamics during mouse spermatogenesis. Nature Communications. 2019; 10(1):1251. [DOI:10.1038/s41467-019-09182-1] [PMID] [PMCID]

[2] Ni FD, Hao SL, Yang WX. Multiple signaling pathways in Sertoli cells: Recent Findings in spermatogenesis. Cell Death \& Disease. 2019; 10(8):541. [DOI:10.1038/s41419-019-1782-z] [PMID] [PMCID]

[3] Griswold MD. Spermatogenesis: The commitment to meiosis. Physiological Reviews. 2016; 96(1):1-17. [DOI:10.1152/physrev.00013.2015] [PMID] [PMCID]

[4] Gutierrez K, Glanzner WG, Chemeris RO, Rigo ML, Comim FV, Bordignon $\mathrm{V}$, et al. Gonadotoxic effects of busulfan in two strains of mice. Reproductive Toxicology. 2016; 59:31-9. [DOI:10.1016/j.reprotox.2015.09.002] [PMID]

[5] Khanehzad M, Abolhasani F, Koruji SM, Ragerdi Kashani I, Aliakbari F. [The roles of Sertoli cells in fate determinations of spermatogonial stem cells (Persian)]. Tehran University Medical Journal. 2016; 73(12):878-87. http://tumj.tums.ac.ir/article-1-7253-en.html

[6] Cioppi F, Casamonti E, Krausz C. Age-dependent de novo mutations during spermatogenesis and their consequences. Advances in Experimental Medicine and Biology. 2019; 1166:29-46. [DOI:10.1007/978-3-03021664-1_2] [PMID]

[7] Fahnenstich J, Nandy A, Milde-Langosch K, Schneider-Merck T, Walther $\mathrm{N}$, Gellersen B. Promyelocytic Leukaemia Zinc Finger protein (PLZF) is a glucocorticoid-and progesterone-induced transcription factor in human endometrial stromal cells and myometrial smooth muscle cells. Molecular Human Reproduction. 2003; 9(10):611-23. [DOI:10.1093/molehr/ gag080] [PMID]

[8] Wang X, Wang J, Zhang L. Characterization of atypical acute promyelocytic leukaemia: Three cases report and literature review. Medicine (Baltimore). 2019; 98(19):e15537. [DOI:10.1097/MD.0000000000015537] [PMID] [PMCID]

[9] Fayomi AP, Orwig KE. Spermatogonial stem cells and spermatogenesis in mice, monkeys and men. Stem Cell Research. 2018; 29:207-14. [DOI:10.1016/j.scr.2018.04.009] [PMID] [PMCID]

[10] Savage AK, Constantinides MG, Han J, Picard D, Martin E, Li B, et al. The transcription factor PLZF directs the effector program of the NKT cell lineage. Immunity. 2008; 29(3):391-403. [DOI:10.1016/j.immuni.2008.07.011] [PMID] [PMCID]

[11] Jin Y, Nenseth HZ, Saatcioglu F. Role of PLZF as a tumor suppressor in prostate cancer. Oncotarget. 2017; 8(41):71317-24. [DOI:10.18632/oncotarget.19813] [PMID] [PMCID]

[12] Liu TM, Lee EH, Lim B, Shyh-Chang N. Concise review: Balancing stem cell self-renewal and differentiation with PLZF. Stem Cells. 2016; 34(2):277-87. [DOI:10.1002/stem.2270] [PMID]

[13] Meistrich ML, Mohapatra B, Shirley CR, Zhao M. Roles of transition nuclear proteins in spermiogenesis. Chromosoma. 2003; 111(8):483-8. [DOI:10.1007/s00412-002-0227-z] [PMID]

[14] Jedrzejczak P, Kempisty B, Bryja A, Mostowska M, Depa-Martynow M, Pawelczyk L, et al. Quantitative assessment of transition proteins 1, 2 spermatid-specific linker histone $\mathrm{H1}$-like protein transcripts in spermatozoa from normozoospermic and asthenozoospermic men. Archives of Andrology. 2007; 53(4):199-205. [DOI:10.1080/01485010701426430] [PMID]
[15] Meistrich ML. Effects of chemotherapy and radiotherapy on spermatogenesis in humans. Fertility and Sterility. 2013; 100(5):1180-6. [DOI:10.1016/j.fertnstert.2013.08.010] [PMID] [PMCID]

[16] Torma F, Koltai E, Nagy E, Mosaferi Ziaaldini M, Posa A, Koch LG, et al. Exercise increases markers of spermatogenesis in rats selectively bred for low running capacity. PLoS One. 2014; 9(12):e114075. [DOI:10.1371/ journal.pone.0114075] [PMID] [PMCID]

[17] Mohaqiq M, Movahedin M, Mazaheri Z, Amirjannati N. Successful human spermatogonial stem cells homing in recipient mouse testis after in vitro transplantation and organ culture. Cell Journal. 2019; 20(4):513-20. [DOI:10.26226/morressier.5af300b3738ab10027aa9b14] [PMID] [PMCID]

[18] Chen H, Tang QL, Wu XY, Xie LC, Lin LM, Ho GY, et al. Differentiation of human umbilical cord mesenchymal stem cells into germ-like cells in mouse seminiferous tubules. Molecular Medicine Reports. 2015; 12(1):819-28. [DOI:10.3892/mmr.2015.3528] [PMID] [PMCID]

[19] Bagheri Hamzian Olya J, Khadem Ansari MH, Yaghmaei P. [The effect of endurance running activities on Prolactin, Testosterone and DHEA-S levels (Persian)]. The Journal of Urmia University of Medical Sciences. 2011; 21(5):391-7. http://umj.umsu.ac.ir/article-1-828-en.html

[20] Taher Z, Hamednia M, Haghighi H. [Investigation of effect of one session moderate and heavy resistance exercise on acute and delayed responses of leptin, insulin, cortisol, testosterone and 24- hour energy expenditure in healthy men (Persian)]. Iranian Journal of Endocrinology \& Metabolism. 2011; 13(1):67-73. http://ijem.sbmu.ac.ir/article-1-871-fa. html

[21] Urhausen A, Kullmer T, Kindermann W. A 7-week follow up study of the behavior of testosterone and cortisol during the competition period in rowers. European Journal of Applied Physiology and Occupational Physiology. 1987; 56(5):528-33. [DOI:10.1007/BF00635365] [PMID]

[22] Manna I, Jana K, Samanta PK. Effect of intensive exercise-induced testicular gametogenic and steroidogenic disorders in mature male Wistar strain rats: A correlative approach to oxidative stress. Acta Physiologica Scandinavica. 2003; 178(1):33-40. [DOI:10.1046/j.1365201X.2003.01095.x] [PMID]

[23] Vaamonde D, Garcia-Manso JM, Hackney AC. Impact of physical activity and exercise on male reproductive potential: A new assessment questionnaire. Revista Andaluza de Medicina del Deporte. 2017; 10(2):79-93. [DOI:10.1016/j.ramd.2016.11.017] [PMID] [PMCID]

[24] Jóźków $P$, Rossato $M$. The impact of intense exercise on semen quality. American Journal of Men's Health. 2017; 11(3):654-62. [DOI:10.1177/1557988316669045] [PMID] [PMCID]

[25] National Research Council, Division on Earth and Life Studies, Institute for Laboratory Animal Research, Committee for the Update of the Guide for the Care and Use of Laboratory Animals. Guide to the care and use of experimental animals. $2^{\text {nd }}$ ed. Ottawa: Canadian Council on Animal Care Ottawa Pub; 1993. https://www.ncbi.nlm.nih.gov/books/NBK54050/

[26] Pfaffl MW. A new mathematical model for relative quantification in real-time RT-PCR. Nucleic Acids Research. 2001; 29(9):e45. [DOI:10.1093/ nar/29.9.e45] [PMID] [PMCID]

[27] Costoya JA, Hobbs RM, Barna M, Cattoretti G, Manova K, Sukhwani M, et al. Essential role of Plzf in maintenance of spermatogonial stem cells. Nature Genetics. 2004; 36(6):653-9. [DOI:10.1038/ng1367] [PMID]

[28] Choi WI, Kim MY, Jeon BN, Koh DI, Yun CO, Li Y, et al. Role of Promyelocytic Leukemia Zinc Finger (PLZF) in cell proliferation and cyclindependent kinase inhibitor $1 \mathrm{~A}$ ( $\mathrm{p} 21 \mathrm{WAF} / \mathrm{CDKN} 1 \mathrm{~A})$ gene repression. The Journal of Biological Chemistry. 2014; 289(27):18625-40. [DOI:10.1074/ jbc.M113.538751] [PMID] [PMCID] 
[29] Hsu YH, Chen YC, Chen TH, Sue YM, Cheng TH, Chen JR, et al. Far-infrared therapy induces the nuclear translocation of PLZF which inhibits VEGF-induced proliferation in human umbilical vein endothelial cells. PLoS One. 2012; 7(1):e30674. [DOI:10.1371/journal.pone.0030674] [PMID] [PMCID]

[30] Kemi OJ, Wislff U. Mechanisms of exercise-induced improvements in the contractile apparatus of the mammalian myocardium. Acta Physiologica (Oxf). 2010; 199(4):425-39. [DOI:10.1111/j.17481716.2010.02132.x] [PMID]

[31] Farup J, Sørensen H, Kjølhede T. Similar changes in muscle fiber phenotype with differentiated consequences for rate of force development: Endurance versus resistance training. Human Movement Science. 2014; 34:109-19. [DOI:10.1016/j.humov.2014.01.005] [PMID]

[32] Snijders T, Nederveen JP, Joanisse S, Leenders M, Verdijk LB, van Loon LC, et al. Muscle fibre capillarization is a critical factor in muscle fibre hypertrophy during resistance exercise training in older men. Journal of Cachexia, Sarcopenia and Muscle. 2017; 8(2):267-76. [DOI:10.1002/ jcsm.12137] [PMID] [PMCID]

[33] Kingsley JD, Figueroa A. Acute and training effects of resistance exercise on heart rate variability. Clinical Physiology and Functional Imaging. 2016; 36(3):179-87. [DOI:10.1111/cpf.12223] [PMID]

[34] Isner-Horobeti ME, Dufour SP, Vautravers P, Geny B, Coudeyre E, Richard R. Eccentric exercise training: Modalities, applications and perspectives. Sports Medicine. 2013; 43(6):483-512. [DOI:10.1007/s40279-0130052-y] [PMID]

[35] Shulman GI, Rothman DL, Jue T, Stein P, DeFronzo RA, Shulman RG. Quantitation of muscle glycogen synthesis in normal subjects and subjects with non-insulin-dependent diabetes by $13 \mathrm{C}$ nuclear magnetic resonance spectroscopy. The New England Journal of Medicine. 1990; 322(4):223-8. [DOI:10.1056/NEJM199001253220403] [PMID]

[36] Pozefsky T, Tancredi RG, Moxley RT, Dupre J, Tobin JD. Effects of brief starvation on muscle amino acid metabolism in nonobese man. The Journal of Clinical Investigation. 1976; 57(2):444-9. [DOI:10.1172/ JCI108295] [PMID] [PMCID] 
This Page Intentionally Left Blank 